\title{
Top 10 Primary Care Training Room Conditions
}

Editors

SIOBHAN M. STATUTA

JOHN M. MACKNIGHT

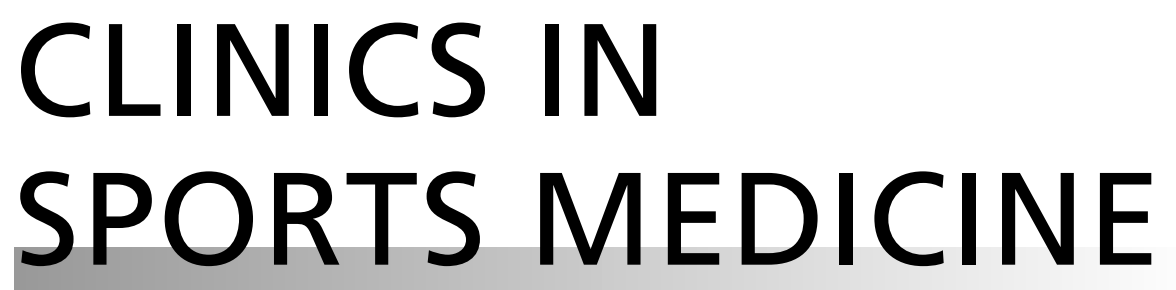

www.sportsmed.theclinics.com

Consulting Editor

MARK D. MILLER

October $2019 \bullet$ Volume $38 \bullet$ Number 4 